\title{
Barbara Miszewska, Robert Szmytkie \\ Rozwój przestrzenny i przemiany morfologiczne osiedli Wrocławia wyrosłych wokół dawnych wsi kmiecych
}

W latach 1928-1973 w granice Wrocławia wcielono trzy miasta (Brochów, Leśnicę i Psie Pole) oraz ponad 50 wsi, w wyniku czego powierzchnia miasta wzrosła z 49,2 do $292,8 \mathrm{~km}^{2}$. Wśród przyłączonych do miasta miejscowości można wyróżnić wsie: warzywnicze, kmiece i folwarczne. W większości przypadków stały się one jądrami genetycznymi, wokół których wyrosły obecne osiedla miasta. Na szczególną uwagę, z uwagi na zróżnicowane tempo i złożony charakter przemian morfologicznych, zasługują zwłaszcza wsie kmiece. Celem artykułu jest analiza rozwoju przestrzennego i głównych tendencji przemian morfologicznych osiedli powstałych w sąsiedztwie wsi kmiecych. Większość $\mathrm{z}$ nich położona jest $\mathrm{w}$ zachodniej i południowej części miasta. Ich wybór podyktowany był zaawansowaniem procesów rozwoju i zróżnicowania morfologicznego osiedli powstałych wokół dawnych wsi i stopniem przekształcenia pierwotnego siedliska wsi (od zachowanej po częściowo zachowaną i całkowicie wymienioną zabudowę zagrodową), od fazy minimalnych zmian pierwotnego układu (Jerzmanowo) po fazę zacierania formy inicjalnej i powstawania swoistej wewnątrzmiejskiego ,zlepieńca” (Ołtaszyn - Wojszyce).

Słowa kluczowe: przemiany morfologiczne, rozwój przestrzenny miasta, morfologia miasta, wsie kmiece, Wrocław.

\section{Wprowadzenie}

Rozwój przestrzenny Wrocławia zapoczątkowany został na początku XIX w. poprzez zarządzoną przez Napoleona likwidację rozległych fortyfikacji miejskich (1807 r.). Uzyskany w ten sposób teren i likwidacja bariery przestrzennej, jaką stanowiły fortyfikacje, umożliwiły „wylanie” się miasta na zewnątrz średniowiecznych granic. Początkowo proces ten przebiegał jednak mało dynamicznie. Przyspieszeniu uległ po uruchomieniu linii kolejowej (1842 r.) i lokalizacji pierwszego dworca kolejowego na południe od miasta lokacyjnego (Maleczyński i in. 1956).

Wychodzące na zewnątrz miasto wkraczało na teren wrocławskich przedmieść: Świdnickiego, Oławskiego, Odrzańskiego i Mikołajskiego oraz rozłogów istniejących od średniowiecza wsi. 
H. Szulc (1963) w granicach współczesnego Wrocławia wyróżniła trzy zasadnicze typy wsi (ryc. 1):

- wsie warzywnicze, położone na południe od miasta w bezpośrednim sąsiedztwie Przedmieścia Świdnickiego;

- wsie kmiece (owalnice i ulicówki), położone wokół miasta, ale głównie na południe od doliny Odry, w części wysoczyznowej z dobrymi czarnymi glebami,

- wsie folwarczne, położone głównie w części dolinnej i na północ od miasta (w tym wsie rybackie).

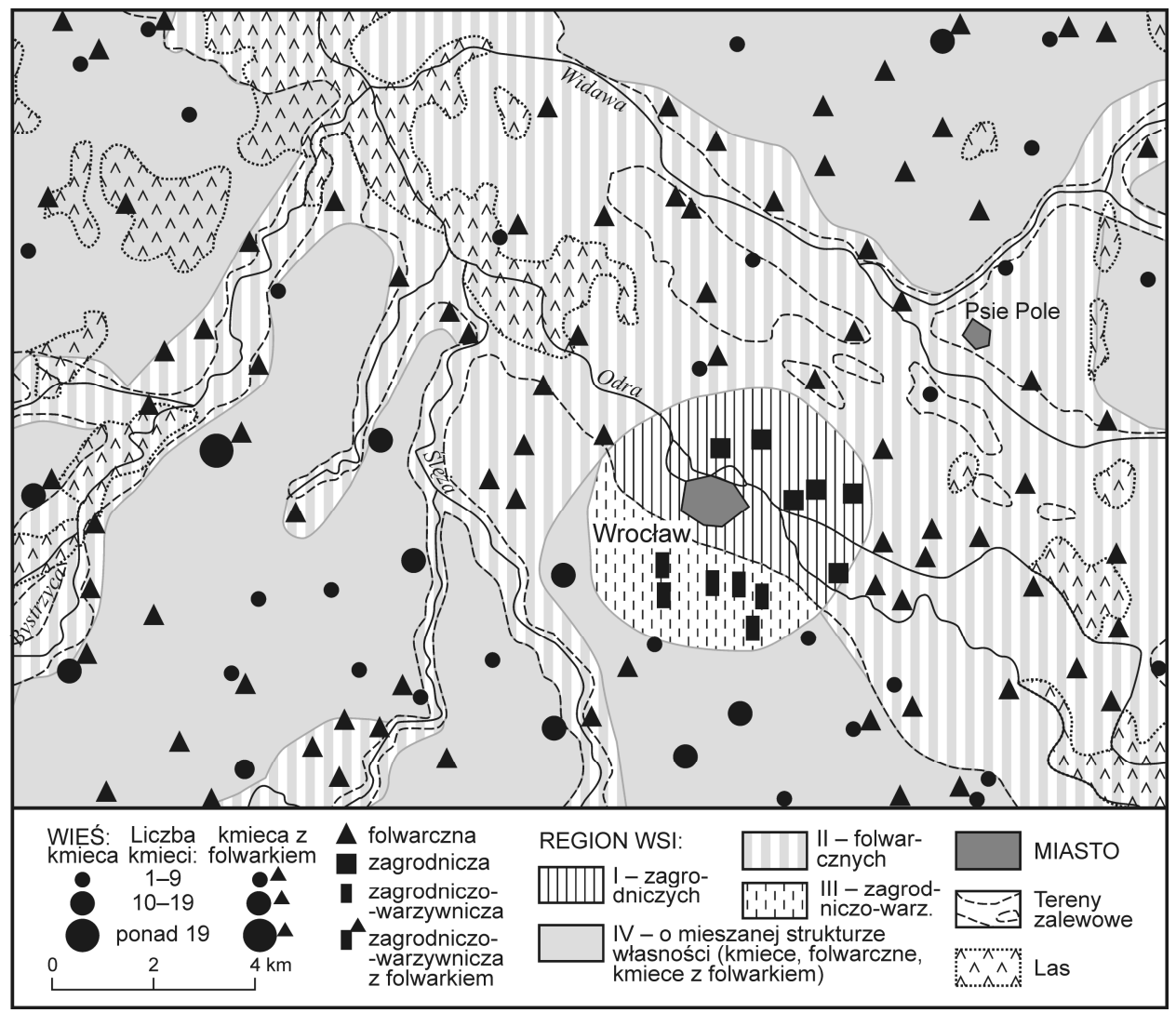

Ryc. 1. Wsie kmiece, warzywnicze i folwarczne w sąsiedztwie Wrocławia na początku XIX w. Źródło: H. Szulc (1963)

Znaczenie tych wsi w rozwoju przestrzennym Wrocławia zostało omówione w pracach: H. Szulc (1963), B. Miszewskiej (1996, 2002), B. Miszewskiej i D. Sikorskiego (2011) oraz B. Miszewskiej i R. Szmytkie (2015). Rola wsi warzywniczych w kształtowaniu fizjonomii kapitalistycznego miasta została 
zaprezentowana w pracy B. Miszewskiej i R. Szmytkie (2015), a rola pozostałych wsi w inicjacji wrocławskich miast-ogrodów i osiedli willowych w pracach B. Miszewskiej (1996, 2002). Badania dotyczące jednostek morfogenetycznych o wiejskim rodowodzie $\mathrm{w}$ strukturze przestrzennej dużych miast prowadzone były również na przykładzie Łodzi (Koter 1979, 1994) i Katowic (Chmielewska 2016).

Konsekwencją rozszerzania się zainwestowania miejskiego było poszerzanie granic Wrocławia (ryc. 2). XIX-wieczne granice miasta obejmowały głównie tereny dawnych przedmieść i wsi warzywniczych. Omawiane w prezentowanym artykule wsie kmiece znalazły się w strefie największych przyłączeń terytorialnych, jakie miały miejsce w 1928 r. i po wojnie w latach: 1951, 1970 i 1973.

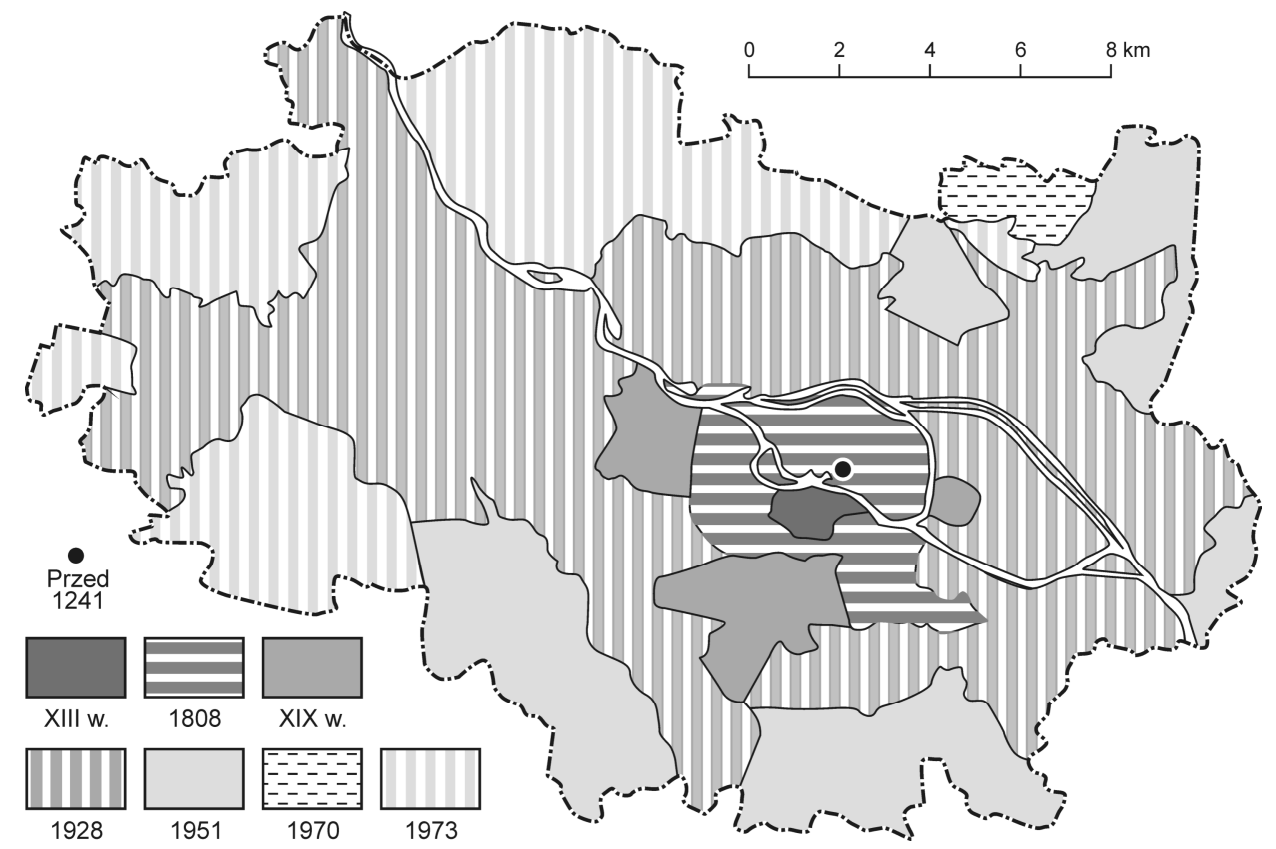

Ryc. 2. Rozwój terytorialny Wrocławia

Źródło: B. Miszewska (2002)

Poszerzenie miasta w 1928 r. miało na celu umożliwienie uzyskania terenów pod budowę osiedli mieszkaniowych dla napływających nowych mieszkańców rozwijającego się dzięki przemysłowi miasta. Był to też okres rozwoju różnorodnych koncepcji urbanistycznych powstających pod wpływem howardowskiej idei miasta ogrodu. Koncepcje te we Wrocławiu (pierwsze osiedla spółdzielcze, a także powstające miasta-ogrody) wprowadzali w życie: architekt i urbanista 
Ernst May, Max Berg i inni (Kononowicz 1997). Zainicjowany w tym czasie rozwój przestrzenny poszczególnych wsi - wchłoniętych przez miasto - trwa $\mathrm{z}$ różną intensywnością do dziś, z wyraźnym przyspieszeniem $\mathrm{w}$ ostatnich dziesięcioleciach.

W prezentowanym artykule skoncentrowano się na rozwoju przestrzennym i zróżnicowaniu morfologicznym dawnych wsi kmiecych. Mimo zachodzących zmian, wsie te charakteryzują się, ze wszystkich wymienionych typów wsi, najlepiej zachowanym jądrem genetycznym w postaci wyraźnego układu pierwotnej wsi owalnicowej lub ulicowej. Przekształcenia fizjonomiczne i morfologiczne tego jądra, jak i postępujące w czasie zróżnicowanie morfologiczne przyrosłych osiedli, wybrano jako kanwę niniejszego artykułu. Zmiany w morfologii dawnych wsi kmiecych (a obecnie osiedli miasta) przedstawiono na przykładzie wybranych bloków urbanistycznych, reprezentujących charakterystyczne dla poszczególnych okresów (okres międzywojenny, lata 1945-1989 i okres współczesny, po 1989 r.) typy zabudowy.

\section{Wsie jako peryferyjne osiedla Wroclawia}

Ekspansja terytorialna Wrocławia zainicjowała rozwój zabudowy, a w konsekwencji przeobrażenia morfologiczne na terenach wcielonych do miasta (ryc. 3). W drugiej połowie XIX w. na dawne wsie warzywnicze wkroczyła typowa dla tego okresu zabudowa czynszowa, przeznaczona dla robotników. Na początku XX w. nastąpiło dalsze zajmowanie dawnych przedmieść i wkraczanie zabudowy na teren wsi warzywniczych, co przyczyniło się do ich funkcjonalnego zaniku. W tym okresie poza tą strefą (na południe i wschód od niej) w pewnej odległości od terenów zwartej zabudowy powstały też pierwsze osiedla willowe, o dużych działkach i bogatych w detale architektoniczne domów, przeznaczone dla coraz liczniejszej we Wrocławiu burżuazji. W okresie międzywojennym w miejscu lub sąsiedztwie dawnych wsi powstały osiedla willowe i o zabudowie szeregowej, przeznaczone dla różnych grup społecznych, zwykle robotników. Po wojnie na ugorach miejskich (w obrębie rozłogów dawnych wsi wcielonych do miasta) lub terenach pełniących inne funkcje powstawały z kolei duże osiedla mieszkaniowe o zabudowie wielkoblokowej lub osiedla willowe (Miszewska 1994).

Adaptacja wsi wcielonych do Wrocławia przyczyniła się do zmian morfologicznych na ich terenie, które polegały na (Miszewska 1996):

1. Wznoszeniu w sąsiedztwie pierwotnego siedliska wsi nowych osiedli mieszkaniowych. Pod zabudowę zajmowano w tym celu część rozłogów wiej- 
skich. Miała więc miejsce sukcesja użytkowania ziemi, a proces taki może być uważany za przejaw suburbanizacji.

2. Zmianie charakteru zabudowy w dotychczasowych wsiach, upodobnianiu się zabudowy do tej we wznoszonych w sąsiedztwie osiedli, przy zachowaniu ulic i często działek. Taki proces jest przejawem swoistej semiurbanizacji.

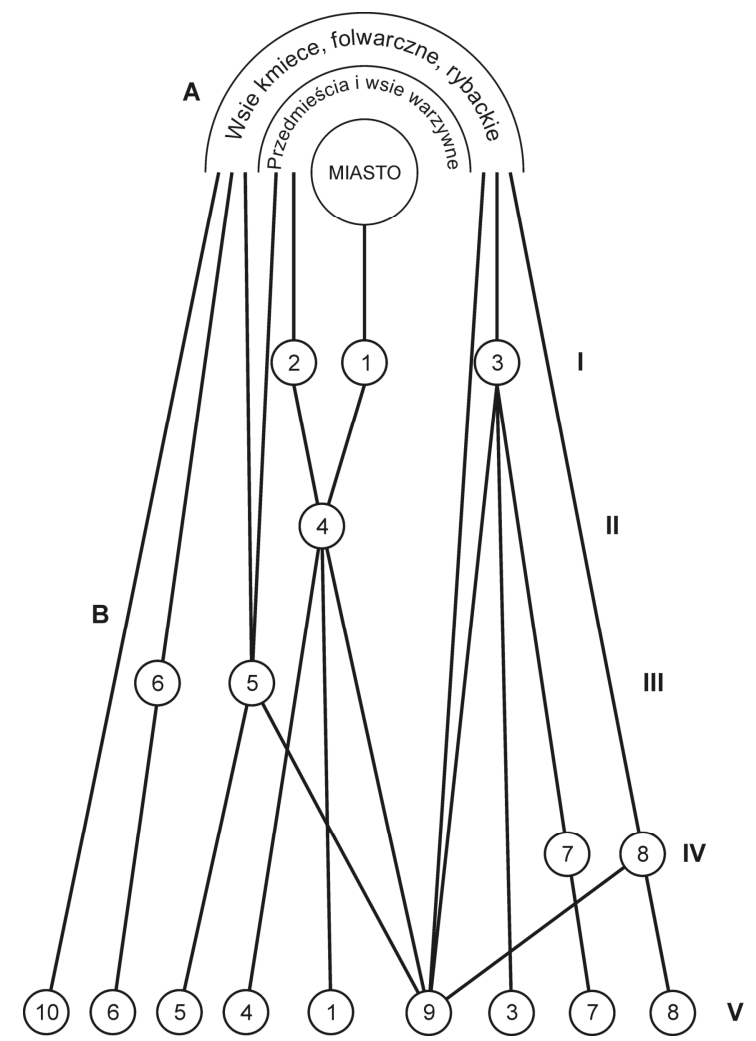

Ryc. 3. Schemat narastania i metamorfozy form morfologicznych na obszarze Wrocławia

I - średniowiecze i okres feudalny, II - druga połowa XIX w., III - początek XX w.,

IV - okres powojenny; jednostki z zabudową: 1 - mieszczańską miasta historycznego,

2 - zagrodową wsi warzywniczych, 3 - zagrodową wsi kmiecych i folwarcznych,

4, 5 - czynszową, 6, 7, 10 - willową i jednorodzinną, 8 - szeregową,

9 - wielorodzinną blokową

Źródło: B. Miszewska (1996)

Proces rozwoju osadnictwa w strefie wsi folwarcznych i kmiecych we Wrocławiu spowodował przekształcenie jej krajobrazu poprzez (Miszewska 1996):

- zmianę użytkowania ziemi, które prowadzi najczęściej do wypierania przez zabudowę terenów użytkowanych rolniczo; 
- rozwój sieci ulicznej, różniącej się od pierwotnego układu ulicznego dawnych wsi, co spowodowało, że stały się one osiedlami o złożonych układach morfologicznych;

- rozwój morfologiczny osiedli, gdzie obok form inicjalnych (wsie rzędownice i folwarki o zachowanych lub zatartych układach) występują jednostki późniejsze: osiedla willowe zlokalizowane głównie w południowej, bardziej atrakcyjnej osadniczo części miasta, oraz osiedla blokowe położone w północno-wschodniej i zachodniej części miasta (ryc. 4).

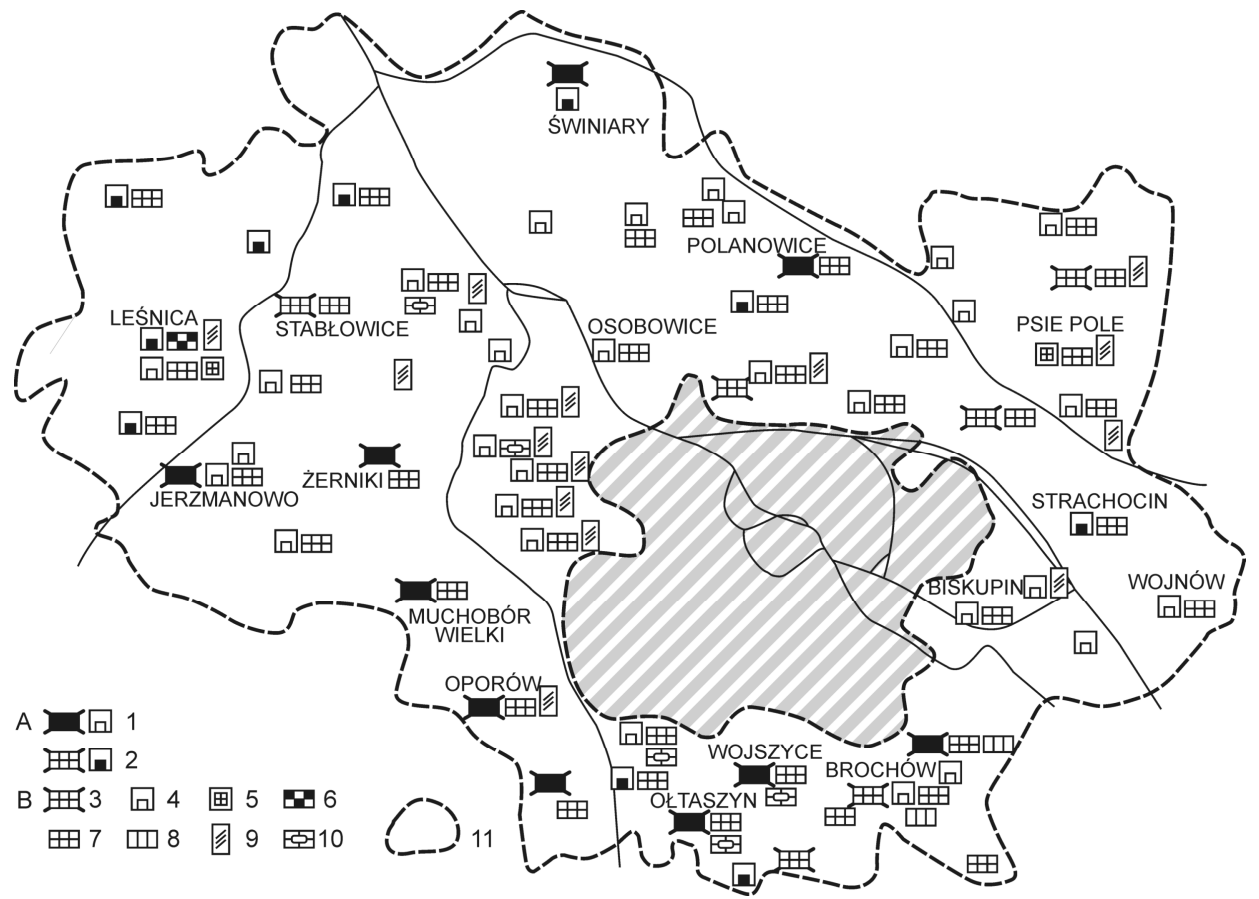

Ryc. 4. Typy jednostek morfologicznych osiedli przyłączonych do Wrocławia po $1928 \mathrm{r}$.

A - według stanu zachowania układu morfologicznego: 1 - wsie o zachowanym

układzie, 2 - wsie o zatartym układzie. B - według typów morfologicznych:

3 - rzędownica, 4 - folwark, 5 - zabudowa czynszowa w przyłączonych miastach.

Osiedla willowe: 6 - z początków XX w., $7-z$ lat międzywojennych, 10 - powojenne.

Zabudowa wielorodzinna: 8 - szeregowa, 9 - wielkoblokowa współczesna, 11 - granica miasta do $1928 \mathrm{r}$.

Źródło: B. Miszewska (1996)

Powstałe w okresie powojennym jednostki morfologiczne cechują się blokami o luźnej wolno stojącej zabudowie, swobodnie usytuowanej we wnętrzu niepodzielonego na działki bloku. Co więcej, nowa zabudowa, z uwagi na zniszczenia wojenne, pojawiła się we wszystkich strefach (ryc. 5). 
Rozwój przestrzenny i przemiany morfologiczne osiedli Wrocławia...

\begin{tabular}{|c|c|c|c|c|c|c|c|c|}
\hline $\begin{array}{l}\text { okresy } \\
\text { morfologiczne }\end{array}$ & & Typy za & udowy w bloka & th urbanistyczny & h w poszczególny & ych strefach gen & etycznych & \\
\hline & & A & & $B$ & & C & & \\
\hline średniowiecze & 国 & & $+H$ & 田 & 开 & Ш & סדس & \\
\hline XIX w. & 田 & 田 & $\boxplus$ & 困田 & 开車 & ष & סחי & \\
\hline $\begin{array}{c}\text { przetom } \\
\text { XIX i XX w. }\end{array}$ & 国 & 田 & 田 & \begin{tabular}{|l|l|} 
田 \\
$E^{\circ}$
\end{tabular} & 开开 & E日 & מדים & \\
\hline $\begin{array}{c}\text { okres } \\
\text { międzywojenny }\end{array}$ & & 田 & 田 & 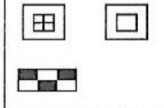 & 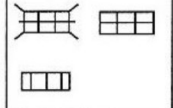 & 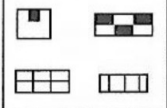 & $\uplus$ & س \\
\hline $\begin{array}{c}\text { okres } \\
\text { powojenny }\end{array}$ & 国 & 田 & 田 目 & $\begin{array}{ll}\text { 田 } \\
\text { 回 }\end{array}$ & 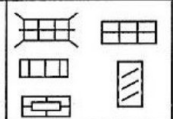 & 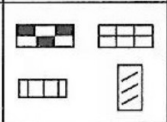 & $\begin{array}{l}E \\
E\end{array}$ & पा \\
\hline
\end{tabular}

Ryc. 5. Typy zabudowy w jednostkach morfologicznych na terenie Wrocławia

I - jednostki o zabudowie wiejskiej: 1 - przedmieść, 2 - wsi warzywniczych, 3 - wsi kmiecych, 4 - wsi folwarcznych, 5 - wsi rybackich; II - jednostki o zabudowie miejskiej: 6 - kamienice mieszczańskie miasta lokacyjnego, 7 - kamienice czynszowe o niskim standardzie, 8 - kamienice czynszowe o wysokim standardzie, 9 - osiedla willowe rezydencjonalne, 10 - osiedla jednorodzinne, 11 - osiedla o zabudowie szeregowej, 12 - osiedla o zabudowie wielkoblokowej, 13 - osiedla willowe współczesne Źródło: B. Miszewska (1995)

Przyczyniło się to m.in. do zaniku kolejnej jednostki inicjalnej - folwarku. W rezultacie $z$ inicjalnych sześciu typów jednostek morfologicznych zachowały się dwie: o zmodernizowanej zabudowie feudalnej (strefa A) i zagrodowej (strefa C), a w miejsce pozostałych powstało na przestrzeni XIX i XX w. siedem nowych.

\section{Ogólna charakterystyka wsi kmiecych}

Wybór wsi podyktowany był zaawansowaniem procesów rozwoju i zróżnicowania morfologicznego osiedli powstałych wokół dawnych wsi oraz stopniem przekształcenia pierwotnego siedliska wsi (od zachowanej po częściowo zachowaną i całkowicie wymienioną zabudowę zagrodową), od fazy minimalnych zmian pierwotnego układu (Jerzmanowo) po fazę zacierania formy inicjalnej i powstawania swoistej wewnątrzmiejskiego ,zlepieńca” (Ołtaszyn - Wojszyce). 
Ten ostatni przykład jest początkiem nowego procesu na terenie Wrocławia - zrastania się przestrzennego izolowanych dotąd osiedli objętych XX-wiecznymi poszerzeniami granic miasta. Zwarta i ciągła zabudowa miasta obejmuje głównie substancję XIX-wieczną i z pierwszych dziesięcioleci XX w. Substancję tę charakteryzuje głównie zabudowa czynszowa o coraz wyższym, w miarę upływu czasu, standardzie. W wybranych do badania jednostkach zabudowa ta występuje jedynie sporadycznie i to głównie w obrębie pierwotnego siedliska wsi. Strefa tej zwartej zabudowy jest wyraźnie w przestrzeni miejskiej izolowana od otaczających osiedli pasem zieleni o różnym charakterze (parki, cmentarze, ogródki działkowe). Zespół osadniczy Ołtaszyn - Wojszyce jest przykładem zbliżania się zabudowy tych izolowanych pierwotnie osiedli do zwartej części miasta.

W sferze zainteresowania znalazły się więc wsie: Jerzmanowo (ryc. 6), Żerniki (ryc. 7), Oporów (ryc. 8), Stabłowice (ryc. 9), Ołtaszyn i Wojszyce (ryc. 10). Wszystkie powstały w XIII w. (częściowo z nadania Henryka Brodatego), najczęściej jako uposażenie wrocławskich kościołów i klasztorów (Antkowiak 1973, Encyklopedia ... 2006). Reprezentują one obowiązujący w okresie kolonizacji średniowiecznej model rozplanowania siedliska i rozłogów. Układ rozłogów miał potem swoje konsekwencje w rozplanowaniu przyrastającej w XX w. zabudowy. Stopień przeobrażeń poszczególnych wsi związany był głównie z ich położeniem $\mathrm{w}$ granicach miasta. Osiedla oddalone $\mathrm{z}$ dala od centrum miasta (o ok. 12-16 km) i od głównych ciągów komunikacyjnych (np. Jerzmanowo lub Żerniki) podlegały znacznie mniej intensywnym przeobrażeniom niż osiedla położone bliżej strefy zwartej zabudowy (np. Ołtaszyn - Wojszyce) (por. Szmytkie 2011).

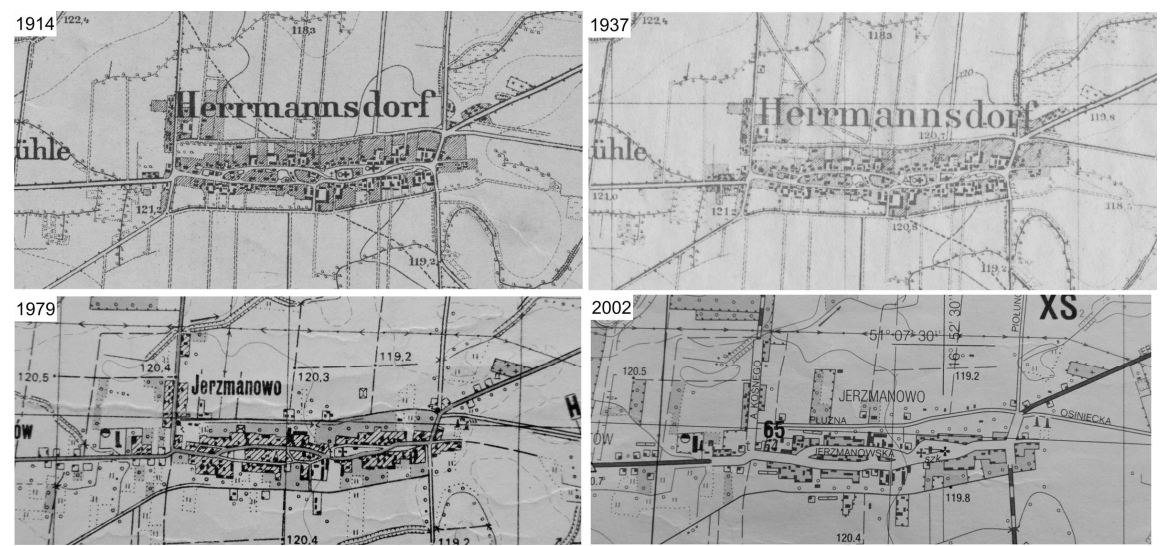

Ryc. 6. Przeobrażenia morfologiczne na terenie dawnej wsi Jerzmanowo Źródło: opracowanie własne 

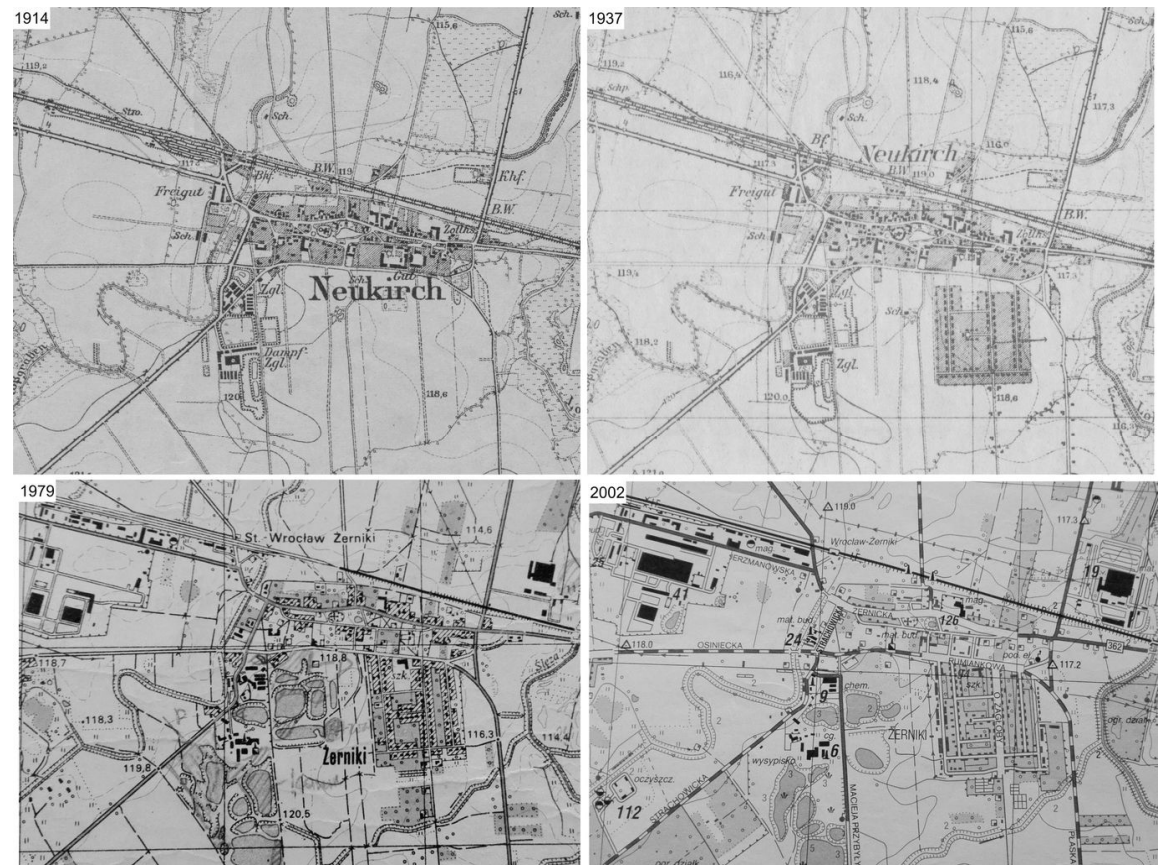

Ryc. 7. Przeobrażenia morfologiczne na terenie dawnej wsi Żerniki Źródło: opracowanie własne
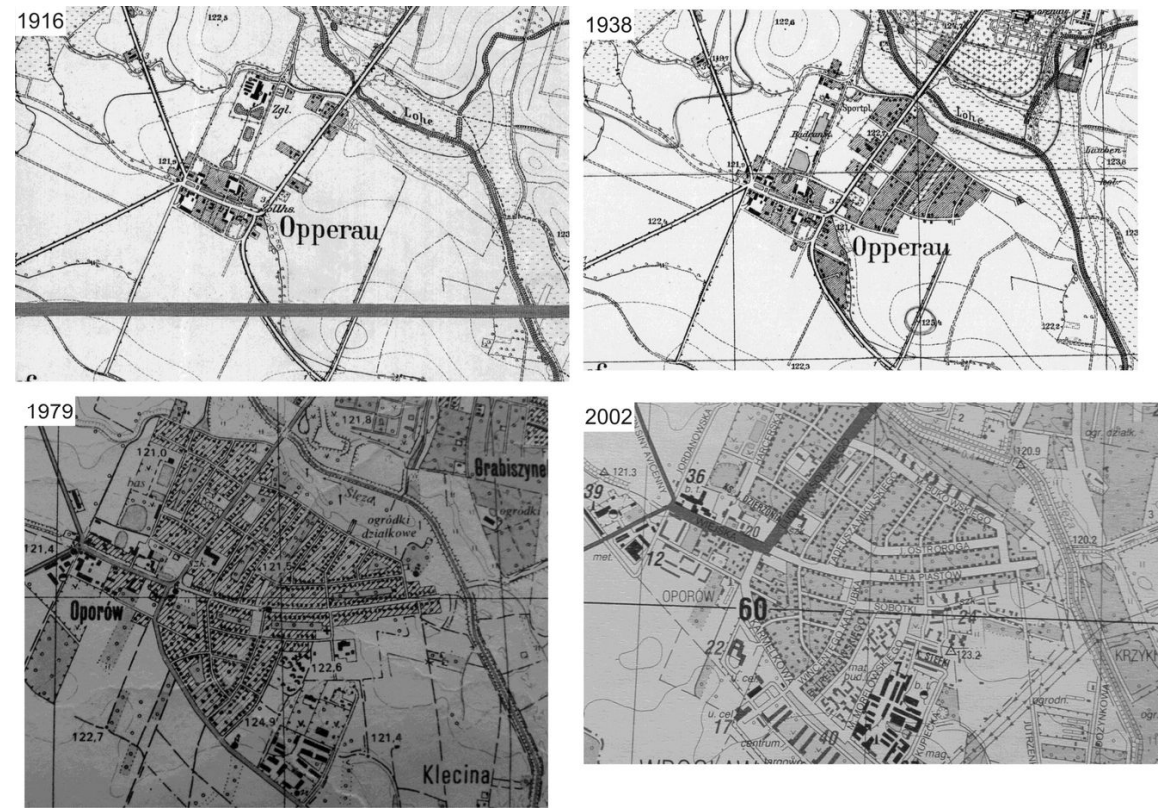

Ryc. 8. Przeobrażenia morfologiczne na terenie dawnej wsi Oporów Źródło: opracowanie własne 

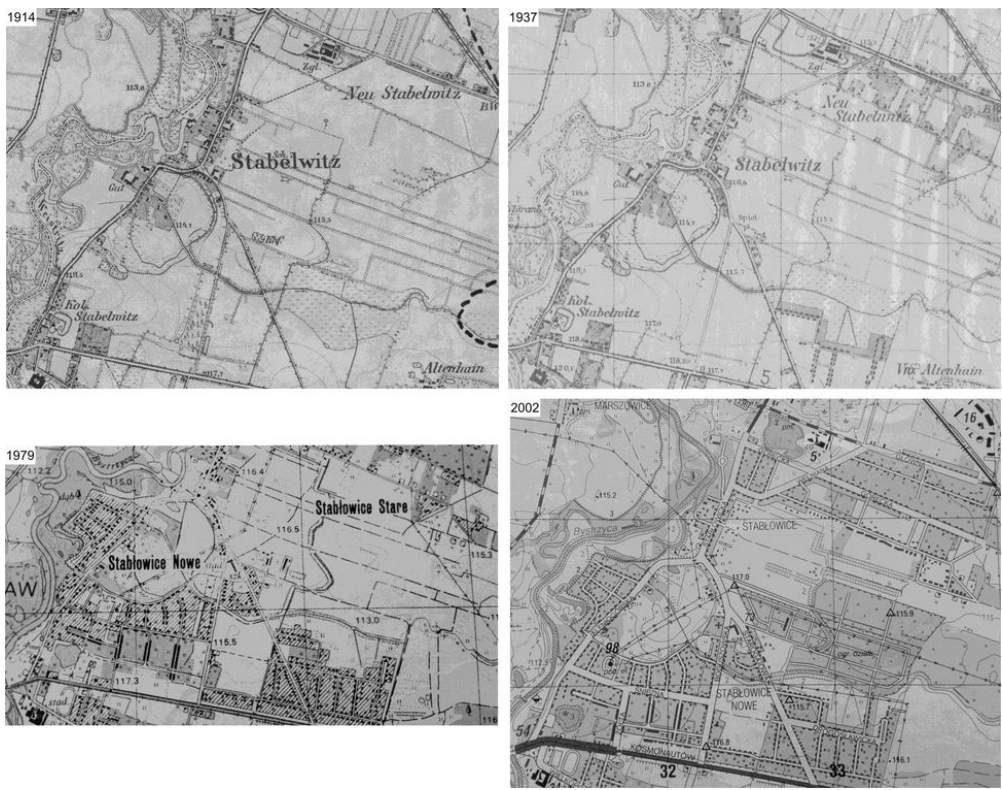

Ryc. 9. Przeobrażenia morfologiczne na terenie dawnej wsi Stabłowice Źródło: opracowanie własne

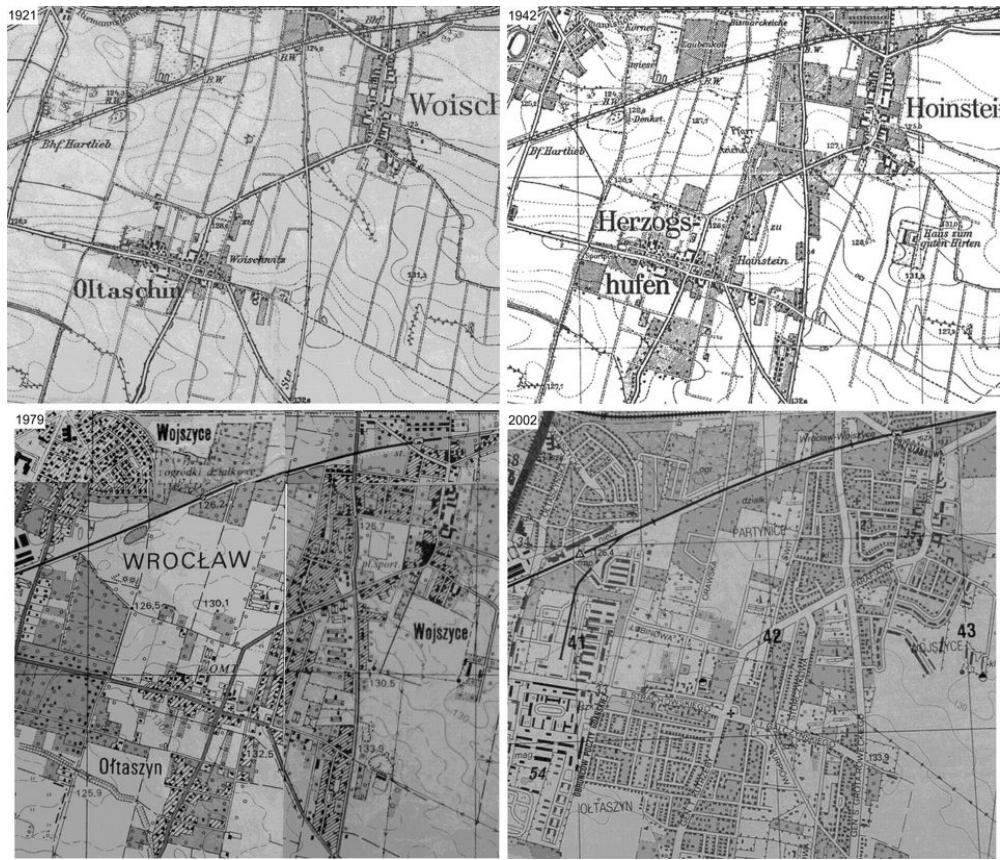

Ryc. 10. Przeobrażenia morfologiczne na terenie dawnych wsi Ołtaszyn i Wojszyce Źródło: opracowanie własne 
Zróżnicowanie powstającej wówczas zabudowy zależało od statusu społecznego przewidywanych mieszkańców. Jak wspomniano wcześniej, rozszerzenie granic miasta wymuszone było naporem ludności napływającej do rozwijającego się przemysłowo Wrocławia oraz koniecznością rozgęszczenia substandardowych czynszowych kamienic w centrum miasta (por. Szmytkie 2011). Dominujący typ zabudowy powstający w tym czasie to zabudowa jednorodzinna lub szeregowa zlokalizowana na niewielkich działkach (ok. 9-12 arów), wykorzystanych na przydomową zieleń lub drobną działalność gospodarczą. Rzadziej była to zabudowa jednorodzinna lub dwurodzinna (ryc. 11) na nieco większych powierzchniowo działkach (ok. 14-16 arów). Odrębnym typem, choć rzadko spotykanym w strefie wsi kmiecych, była zabudowa wielorodzinna, która powstawała głównie w sąsiedztwie lokalnych zakładów przemysłowych.

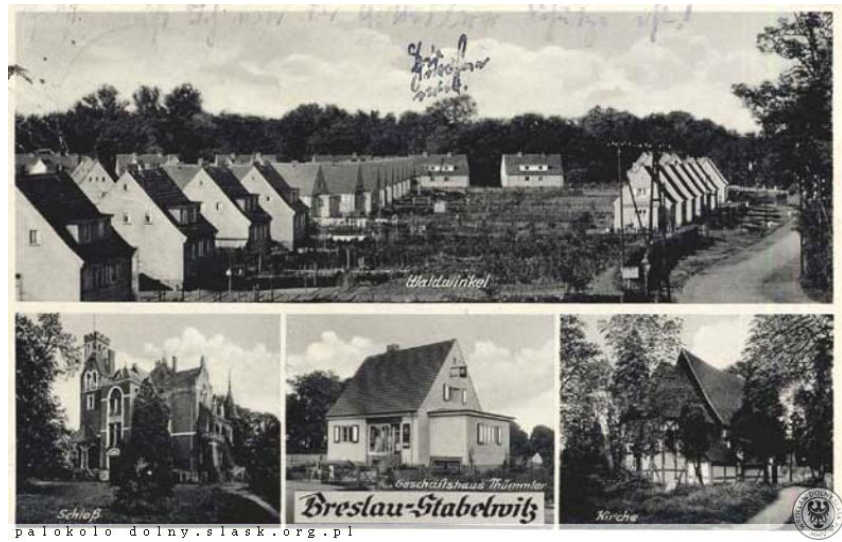

Ryc. 11. Zabudowa jednorodzinna z okresu międzywojennego, Stabłowice Źródło: dolny-slask.org.pl

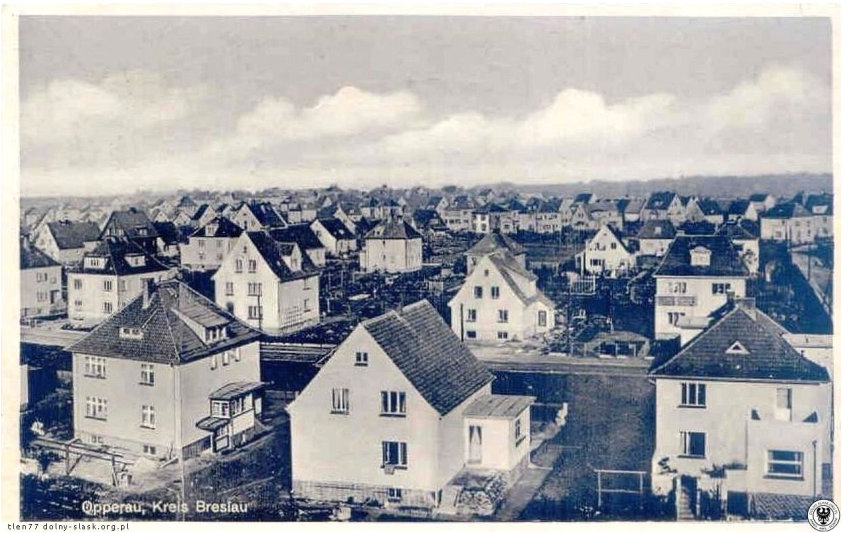

Ryc. 12. Zabudowa willowa z okresu międzywojennego, Oporów Źródło: dolny-slask.org.pl 
Cechą charakterystyczną powstających osiedli był stosunkowo duży udział zieleni przydomowej i osiedlowej $\mathrm{w}$ ich granicach. Taką cechą była również zieleń rzadszych osiedli willowych (ryc. 12), które w badanych wsiach zaczęły powstawać w okresie międzywojennym. Rezydencjonalny charakter zabudowy powielał w skromniejszej formie osiedla willowe z przełomu wieków powstałe w innych częściach Wrocławia, głównie na gruntach dawnych wsi folwarcznych (mniejsze działki, skromniejsza architektura domów) (Miszewska 1994).

Wykształcony - w fazie początkowej rozbudowy osiedli - typ zabudowy realizowany jest do dziś. Zmianie uległa architektura domów, rozplanowanie działek, ich wielkość, sposób wypełnienia, kompozycja układu działek (struktura), także to, co bardzo zmienia fizjonomię osiedli - inny od dotychczasowej rodzaj zieleni przydomowej.

\section{Zróżnicowanie morfologiczne charakteryzowanych wsi}

Przykładem zabudowy willowej z okresu międzywojennego jest blok urbanistyczny między ulicami: Bukowskiego, Mikulskiego, Pękalskiego i Petrażyckiego na Oporowie. Blok ten ma wymiary $250 \mathrm{~m}$ na $110 \mathrm{~m}$ (powierzchnia ok. 275 arów) i pierwotnie podzielony był na 19 działek o średniej powierzchni 14,5 arów. Przed 1945 r. przeważała tu zabudowa willowa, dwukondygnacyjna o znacznej kubaturze, a stopień wypełnienia bloku zabudową wynosił ok. 9\%. W okresie powojennym blok ten, co jest typowe w przypadku międzywojennych osiedli willowych na terenie Wrocławia, został dogęszczony zabudową willową, głównie z lat 70. i 80. Obecnie blok podzielony jest na 29 działek o średniej powierzchni 10 arów, a wypełnienie bloku zabudową wynosi ok. 12\% (ryc. 13).
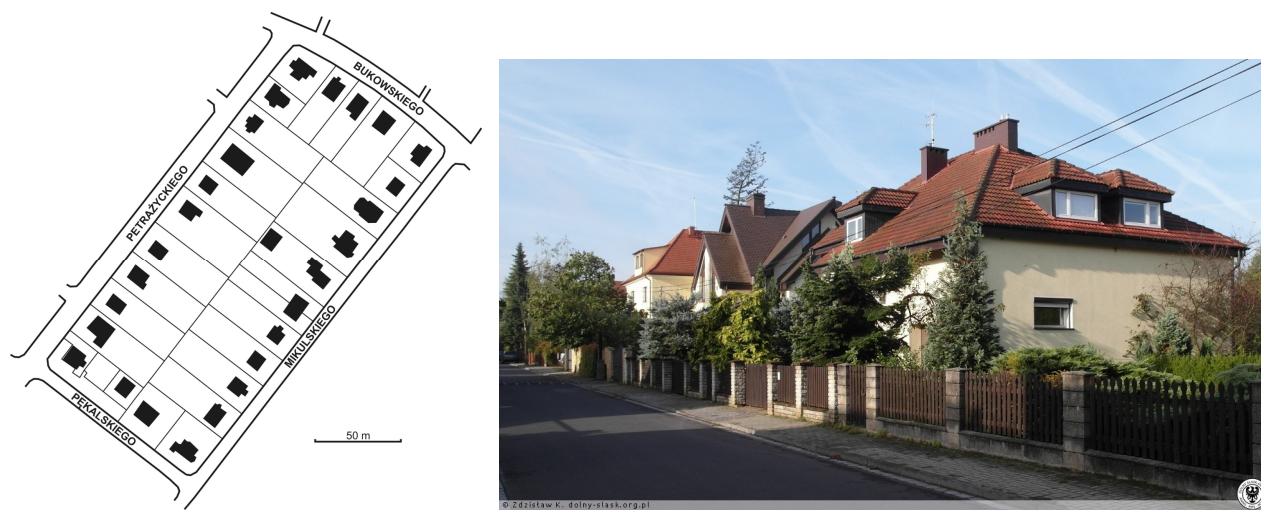

Ryc. 13. Blok urbanistyczny z zabudową willową z okresu międzywojennego na Oporowie i zabudowa przy ulicy Mikulskiego Źródło: opracowanie własne i dolny-slask.org.pl 
W tym czasie powstawały również osiedla o zabudowie jednorodzinnej przeznaczone dla robotników i ich rodzin. Zwykle zlokalizowane były w znacznym oddaleniu od centrum miasta, głównie w jego zachodniej części. Przykładem zabudowy jednorodzinnej robotniczej $\mathrm{z}$ tego okresu jest blok urbanistyczny między ulicami: Ciechocińską, Jeleniogórską, Iwonicką i Sobieszowską na osiedlu Stabłowice. Blok ten ma wymiary ok. $130 \mathrm{~m}$ na $95 \mathrm{~m}$ i zajmuje powierzchnię 125 arów. Został podzielony na 12 podobnej wielkości działek o średniej powierzchni ok. 10 arów. Dość duża powierzchnia poszczególnych działek wynikała z ich przeznaczenia na przydomowe ogródki. Stopień wypełnienia bloku zabudową wynosi obecnie ok. 9\% (ryc. 14).

$\mathrm{Na}$ rozłogach dawnych wsi kmiecych wcielonych do Wrocławia w $1928 \mathrm{r}$. powstawały również obiekty dotąd nie występujące na ich obszarze, których powstanie związane było z ekspansją miejskich form zagospodarowania terenu, jak np. jednostki wojskowe. Jedna z nich powstała na Ołtaszynie, na południe od obecnej ulicy Zwycięskiej. W okresie powojennym koszary Wehrmachtu zostały przejęte przez Armię Czerwoną, która stacjonowała tu do 1993 r. (Antkowiak 1973, Encyklopedia... 2006). Na przełomie XX i XXI w. budynki powojskowe zostały zmodernizowane i przystosowane na osiedle o zabudowie wielorodzinnej (ryc. 15). W północnej części obszaru nastąpiła całkowita wymiany zabudowy. W miejscu zabudowań powojskowych powstały budynki wielorodzinne z placówkami usługowymi na parterach. Południowa część obszaru zachowała pierwotny układ zabudowy. Ma ona wymiary $210 \mathrm{~m}$ na $305 \mathrm{~m}$ i zajmuje powierzchnię 640 arów. Zachowało się tu 12 budynków wielorodzinnych, a stopień wypełnienia bloku zabudową wynosi 16,5\% (ryc. 16).
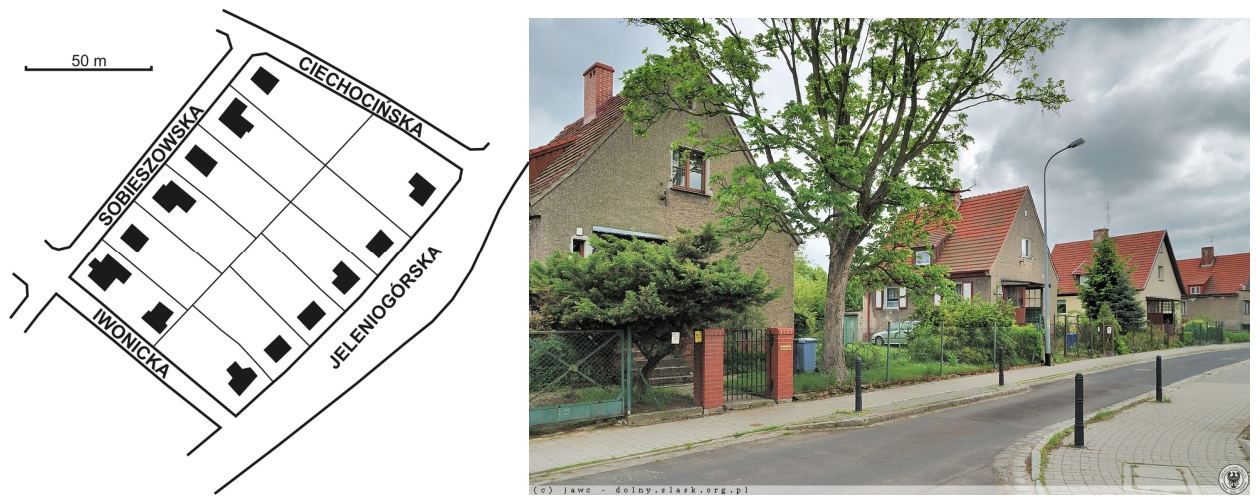

Ryc. 14. Blok urbanistyczny z zabudową jednorodzinną z okresu międzywojennego na Stabłowicach i zabudowa przy ulicy Sobieszowskiej

Źródło: opracowanie własne i dolny-slask.org.pl 


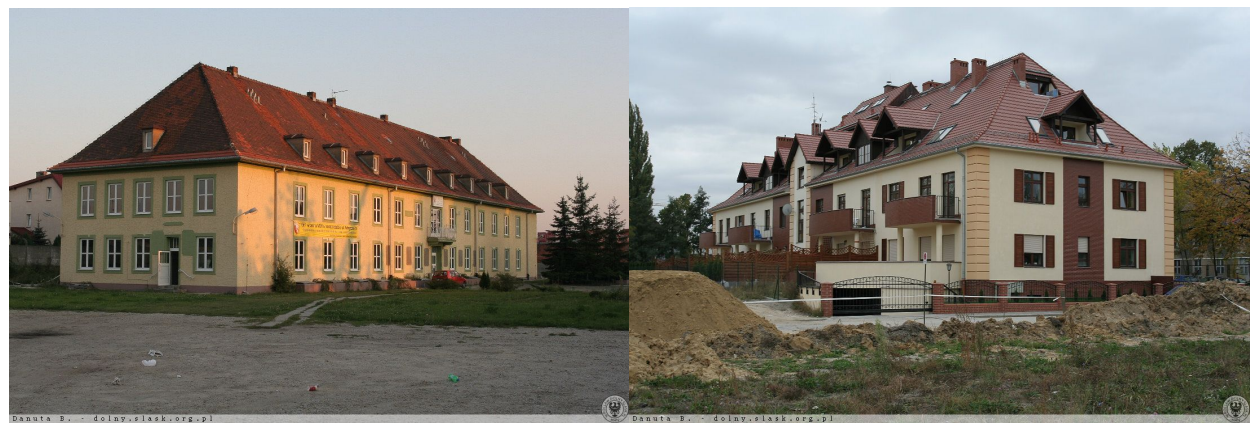

Ryc. 15. Zabudowa na terenie dawnej jednostki wojskowej przy ulicy Zwycięskiej

(Ołtaszyn) przed i po modernizacji

Źródło: dolny-slask.org.pl

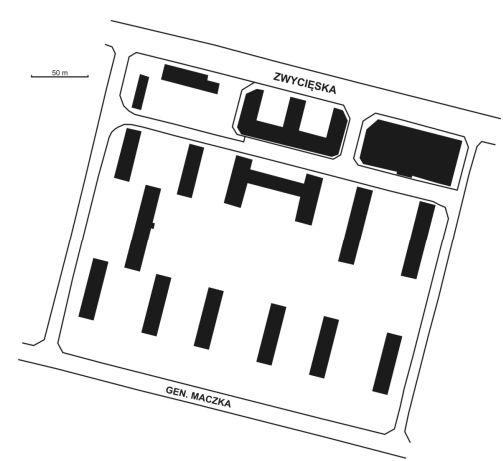

Ryc. 16. Współczesna zabudowa na terenie dawnej jednostki wojskowej przy ulicy Zwycięskiej (Ołtaszyn)

Źródło: opracowanie własne

W okresie powojennym miał miejsce dalszy rozwój terytorialny Wrocławia. Kolejne przyłączenia w latach 1950, 1970 i 1973 spowodowały znaczne poszerzenie granic miasta. Na rozłogach wsi kmiecych wcielonych do miasta postępował rozwój zabudowy. Nowe budynki, głównie jednorodzinne lub willowe, często powstawały w obrębie istniejących już bloków urbanistycznych, prowadząc do ich wtórnego zagęszczenia. Nowa zabudowa powstawała też na terenach dotąd niezabudowanych. Przykładem jest blok urbanistyczny położony między ulicami: Abrahama, Czołgistów, Unruga i Sucharskiego na Ołtaszynie. Ma on wymiary $170 \mathrm{~m}$ na $80 \mathrm{~m}$ i zajmuje powierzchnię ok. 135 arów. Występuje tu zabudowa willowa bliźniacza z lat 70. i 80. XX w. Blok ten jest podzielony na 31 niewielkich, w przeciwieństwie do tych $\mathrm{z}$ okresu międzywojennego, działek (o średniej powierzchni ok. 4 arów), a stopień wypełnienia bloku zabudową wynosi aż 20,5\% (ryc. 17).

Bardziej znaczące zmiany morfologiczne na terenie dawnych wsi kmiecych wystąpiły na przełomie XX i XXI w. Transformacja społeczno-gospodarcza uruchomiła intensywne procesy suburbanizacji w otoczeniu Wrocławia (Kajdanek 
2011, Mayer, Szmytkie 2014), a także rozwój tzw. wewnętrznych suburbiów, które objęły peryferyjne osiedla miasta (Płachta, Szmytkie 2012), w tym rozłogi dawnych wsi kmiecych. Na ich terenie w dalszym ciągu powstają osiedla o zabudowie willowej, czego przykładem jest Osiedle Malownicze, leżące na południe od Marszowic. Typowy blok urbanistyczny, położony między ulicami: Modelskiego, Jahna, Hartmana i Czaplińskiego, o wymiarach ok. $245 \mathrm{~m}$ na $105 \mathrm{~m}$ i powierzchni 260 arów, podzielony jest na 18 działek o średniej powierzchni 14 arów. Stopień wypełnienia bloku zabudową wynosi ok. 13\%. Występuje tu zabudowa willowa z początku XXI w. o znacznej kubaturze, obejmująca budynki liczące zwykle 2,5 kondygnacji i ponad $200 \mathrm{~m}^{2}$ powierzchni użytkowej (ryc. 18).
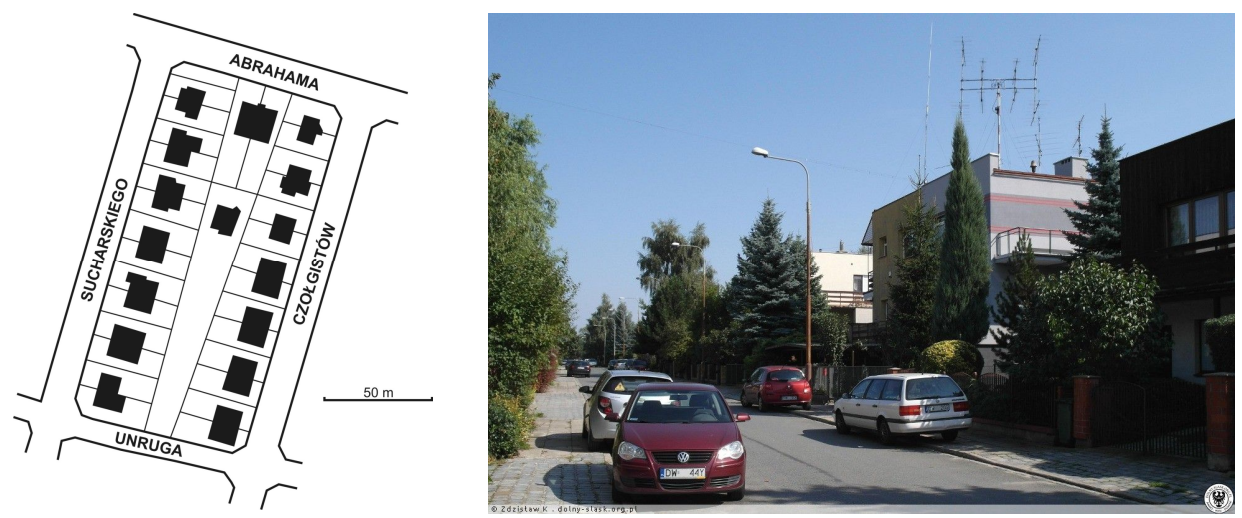

Ryc. 17. Blok urbanistyczny z zabudową willową z lat 70. i 80. XX w. na Ołtaszynie i zabudowa przy ulicy Czołgistów Źródło: opracowanie własne i dolny-slask.org.pl
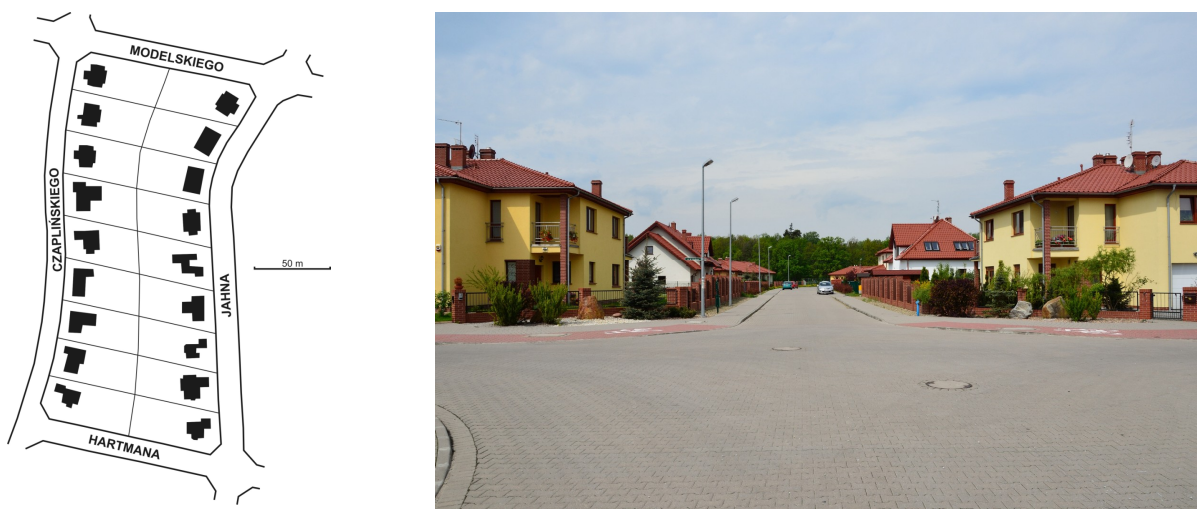

Ryc. 18. Blok urbanistyczny z zabudową willową z początku XXI w. na Osiedlu Malowniczym (Marszowice) i zabudowa przy ulicy Czaplińskiego Źródło: opracowanie własne i dolny-slask.org.pl 
Obecnie w strefie zewnętrznej Wrocławia znacznie częściej powstają jednak osiedla deweloperskie o zabudowie wielorodzinnej. Przykładem może być osiedle na Klecinie (blok urbanistyczny między ulicami: Cukrową, Migdałową i Sezamkową) czy na Stabłowicach (zabudowa przy ulicy Wojanowskiej). Pierwszy obszar ma wymiary $175 \mathrm{~m}$ na $65 \mathrm{~m}$ i zajmuje powierzchnię 115 arów. Od ulicy Cukrowej znajduje się zabudowa $\mathrm{z}$ okresu międzywojennego, natomiast pozostałą część bloku wypełniają współczesne budynki wielorodzinne (osiem bloków o różnej kubaturze). Stopień wypełnienia bloku zabudową wynosi ok. 28\% (ryc. 19).
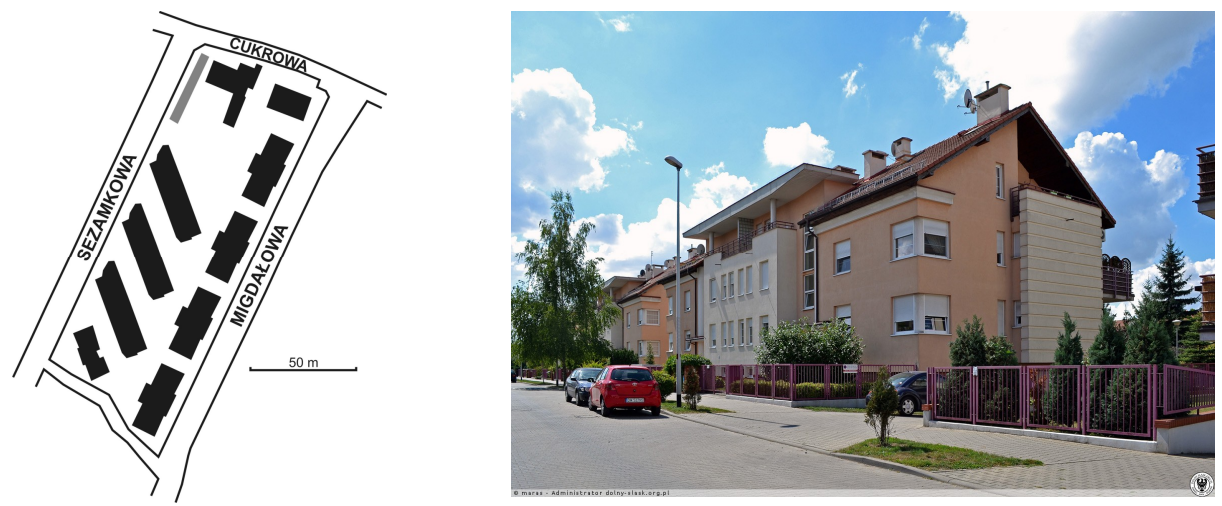

Ryc. 19. Blok urbanistyczny z zabudową wielorodzinną z początku XXI w. na Klecinie i zabudowa przy ulicy Migdałowej Źródło: opracowanie własne i dolny-slask.org.pl

Osiedle przy ulicy Wojanowskiej zostało posadowione na rozległej działce o powierzchni ok. 775 arów. Na jego terenie znajduje się 27 budynków pięciokondygnacyjnych, a stopień wypełnienia działki zabudową wynosi ok. 13\% (ryc. 20).

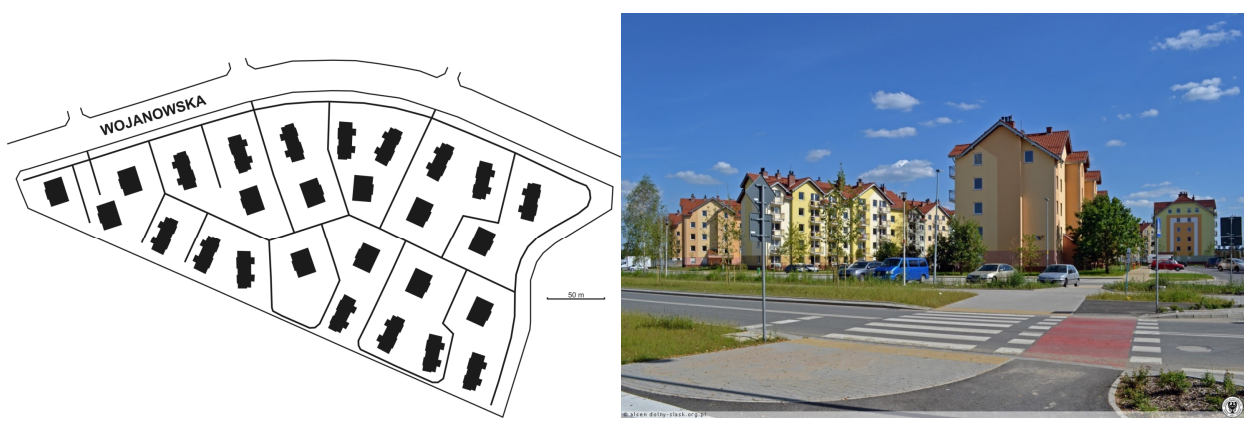

Ryc. 20. Zabudowa wielorodzinną z początku XXI w. przy ulicy Wojanowskiej (Stabłowice) Źródło: opracowanie własne i dolny-slask.org.pl 


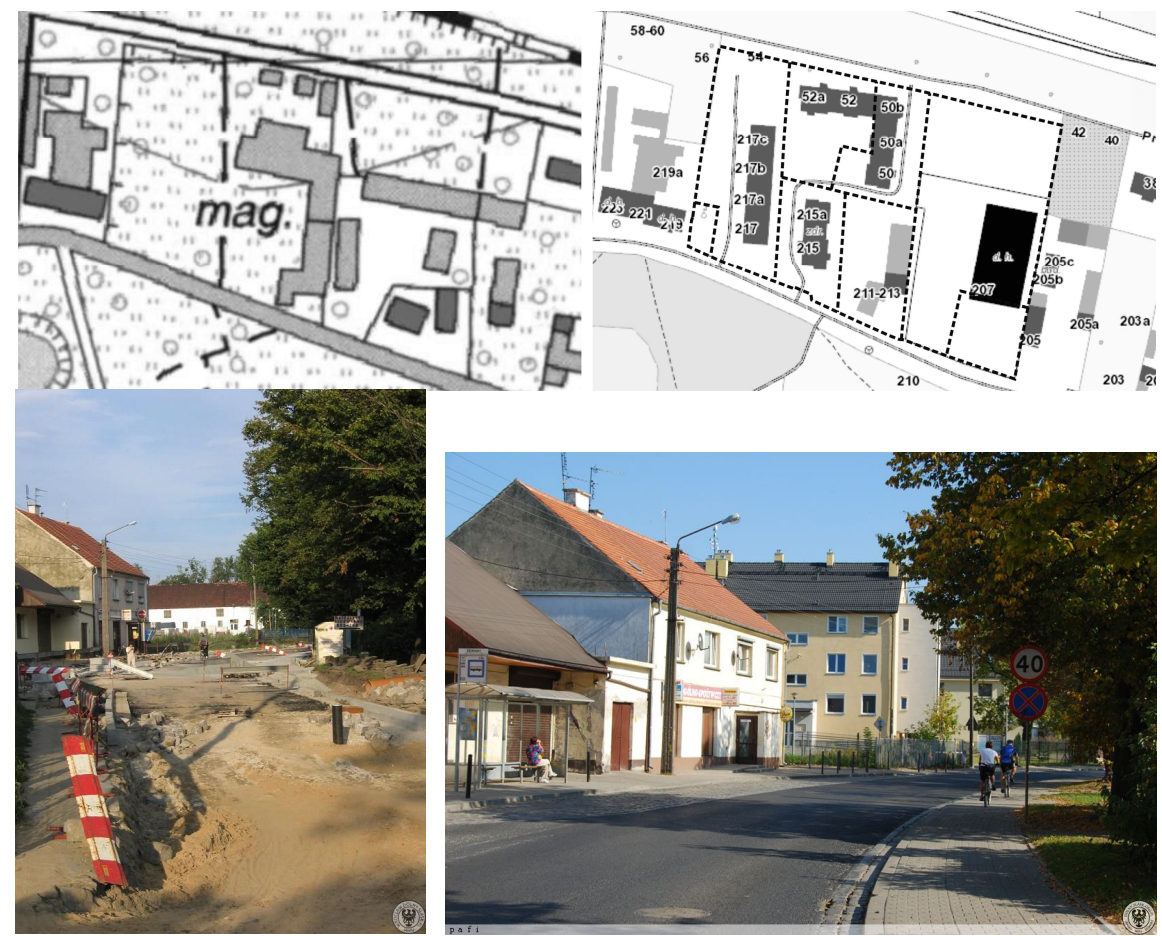

Ryc. 21. Wymiana zabudowy w obrębie siedliska dawnej wsi Żerniki Źródło: opracowanie własne i dolny-slask.org.pl

Nowym zjawiskiem w strefie wsi kmiecych we Wrocławiu jest stopniowa wymiana zabudowy w obrębie ich pierwotnego siedliska. Dobrym przykładem tego procesu są zmiany morfologiczne na Żernikach. W południowej części siedliska wsi do końca XX w. znajdowało się gospodarstwo rolne należące do Zgromadzenia Sióstr Maryi Niepokalanej. Na początku XXI w. teren został sprzedany deweloperom, a w miejscu dawnych budynków gospodarczych powstały trzy bloki wielorodzinne liczące 3,5 kondygnacji i sklep sieci Biedronka. $\mathrm{Z}$ dawnego gospodarstwa rolnego pozostał jedynie fragment budynku zagrodowego. Wymiana zabudowy nie spowodowała jednak znaczących zmian w stopniu wypełnienia bloku (pierwotnie wynosił on 19,3\%, a obecnie 18,8\%) (ryc. 21).

\section{Podsumowanie}

Mimo różnego tempa przeobrażeń, na rozłogach dawnych wsi kmiecych, znajdujących się obecnie w granicach Wrocławia, w różnych okresach (okres międzywojenny, lata 1945-1989, przełom XX i XXI w.) powstawały podobne 
jednostki morfologiczne, różniące się jednak wielkością działek, stopniem wypełnienia bloku zabudową czy fizjonomią budynków. Aż do lat 90. XX w. w strefie wsi kmiecych budowano głównie osiedla o zabudowie willowej lub jednorodzinnej indywidualnej. Obok nich powstają również osiedla o zabudowie wielorodzinnej, tworzące pierścień tzw. wewnętrznych suburbiów Wrocławia. Warto jednak zwrócić uwagę na zróżnicowane tempo przeobrażeń, jakim po inkorporacji w granice miasta podlegały poszczególne wsie kmiece, i różnice $\mathrm{w}$ morfologii osiedli powstających w różnych okresach morfogenetycznych. Najbardziej znaczące zmiany zaszły na terenie wsi położonych w południowej części Wrocławia (tzn. Ołtaszyn - Wojszyce, Oporów, Klecina), co nawiązuje do naturalnego kierunku rozwoju przestrzennego miasta (por. Szmytkie 2011). Miejscowości leżące w znacznym oddaleniu od centrum miasta - ok. 12-16 km (np. Jerzmanowo, Żerniki, Marszowice) rozbudowywane były mniej intensywnie. Różnice w morfologii najlepiej widać na przykładzie osiedli willowych. W okresie międzywojennym działki miały znaczne rozmiary (12-16 arów), a ich przestrzeń w dużym stopniu wypełniała zieleń, a w przypadku osiedli robotniczych przydomowe ogródki lub działalność gospodarcza. Bloki powstałe w latach 1945-1989 dzielono na mniejsze działki (4-8 arów), a znaczna część bloków urbanistycznych z okresu międzywojennego została wtórnie dogęszczona zabudową (np. Oporów, Stabłowice, Żerniki). Osiedla powstające po 1989 r. cechują się różną wielkością działek (w zależności od statusu społecznego mieszkańców), choć zazwyczaj bloki urbanistyczne dzielone są na duże powierzchniowo działki (podobnie jak w okresie międzywojennym) przeznaczone dla klasy średniej. Dla ludności mniej zamożnej, na rozłogach wsi kmiecych, zwłaszcza tych leżących w południowej części miasta, powstają wielorodzinne osiedla deweloperskie. Pewnym novum są natomiast przeobrażenia w obrębie pierwotnego siedliska wsi kmiecych, gdzie dochodzi do wymiany zabudowy (w miejscu zabudowy zagrodowej lub jednorodzinnej powstaje głównie zabudowa wielorodzinna). We wcześniejszych okresach zabudowa wielorodzinna w strefie wsi kmiecych powstała stosunkowo rzadko i zwykle nie tworzyła zwartych osiedli.

\section{Literatura}

Antkowiak Z., 1973, Stare i nowe osiedla Wroctawia, Wrocław.

Chmielewska M., 2016, Morfologiczne przeksztatcenia przestrzeni miejskiej Katowic, Katowice.

Encyklopedia Wrocławia, 2006, Wrocław. 
Kajdanek K, 2011, Pomiędzy miastem a wsia. Suburbanizacja na przykładzie osiedli podmiejskich Wrocławia, Kraków.

Kononowicz W., 1997, Wrocław: kierunki rozwoju urbanistycznego w okresie międzywojennym, Wrocław.

Koter M., 1979, Struktura morfogenetyczna wielkiego miasta na przykładzie Łodzi, „Acta Universitatis Lodziensis”, Nauki Matematyczno-Przyrodnicze, seria 2, z. 21.

Koter M., 1994, Rola wiejskich elementów morfologicznych w procesie ksztattowania układu przestrzennego Lodzi, [w:] M. Koter, J. Tkocz (red.), Zagadnienia geografii historycznej osadnictwa w Polsce, Torun-Lódź, s. 63-88.

Maleczyński K., Morelowski M., Ptaszycka A., 1956, Wrocław. Rozwój urbanistyczny, Warszawa.

Mayer M., Szmytkie R., 2014, Ksztattowanie się stref podmiejskich wokół miast średniej wielkości (studia przypadków z regionu południowo-zachodniego), [w:] Jezierska-Thöle A., Biczkowski M. (red.), Zintegrowany rozwój obszarów wiejskich $w$ świetle polityki Unii Europejskiej, t. 2: Wielofunkcyjność obszarów wiejskich, Toruń, s. $121-152$.

Miszewska B., 1994, Bloki urbanistyczne Wrocławia w różnych fazach cyklu miejskiego, [w:] Koter M., Tkocz J. (red.), Zagadnienia geografii historycznej i osadnictwa w Polsce, Toruń-Łódź, s. 111-129.

Miszewska B., 1995, Wpływ ekspansji przestrzennej Wrocławia na sukcesję użytkowania ziemi i strukturę morfologiczna miasta, „Czasopismo Geograficzne”, 66, s. 363-370.

Miszewska B., 1996, Struktura morfologiczna peryferyjnych osiedli Wrocławia, „Acta Universitatis Wratislaviensis", 1904, s. 53-61.

Miszewska B., 2002, Wsie jako jądra genetyczne osiedli Wrocławskich, „Rocznik Wrocławski”, 8, s. 107-119.

Miszewska B., Sikorski D., 2011, Blokowiska a dewaloryzacja przestrzeni miejskiej na przykładzie południowej dzielnicy Wrocławia, [w:] Jażdżewska I. (red.), Osiedla blokowe $w$ strukturze przestrzennej miast, seria: XXIII Konwersatorium Wiedzy o Mieście, Łódź, s. 127-139.

Miszewska B., Szmytkie R., 2015, Morphological processes in the spatial structure of the southern district of Wroctaw city, „Bulletin of Geography. Socio-economic Series", 27, s. 133-151.

Płachta O., Szmytkie R., 2012, Nowa zabudowa mieszkaniowa jako „inna jakość” w przestrzeni wybranych osiedli Wrocławia, [w:] Jakóbczyk-Gryszkiewicz J. (red.), Procesy gentryfikacji w mieście, cz. 1, seria: XXV Konwersatorium Wiedzy o Mieście, Łódź, s. 135-152.

Szmytkie R., 2011, Osiedla wiejskie $w$ granicach administracyjnych dużego miasta (przykład Wrocławia), [w:] Słodczyk J. (red.), Procesy suburbanizacji w wybranych miastach Polski, seria: Studia Miejskie, 3, Opole, s. 159-186.

Szulc H., 1963, Osiedla podwrocławskie na początku XIX wieku, Wrocław. 


\title{
Spatial development and morphological transformations \\ of districts arisen around former peasant villages The case study of the Wroclaw city
}

\begin{abstract}
Summary
Between the years 1928 and 1973, three towns (Brochów, Leśnica, Psie Pole) and over 50 villages were incorporated into the borders of Wrocław city. It resulted in the growth of the administrative area of the city from 49.2 to $292.8 \mathrm{~km}^{2}$. Amongst the settlements incorporated into the city borders, it is possible to recognize the vegetable, peasant and farm villages. In most cases, former villages became genetic cores, around which current districts of the city were developed. Due to the diversified dynamics and the complex character of morphological transformations, the peasant villages deserve particular attention. An analysis of the spatial development and the main tendencies of morphological transformations of settlements developed around the peasant villages is the main purpose of this article. The majority of peasant villages are located in the western and southern parts of the city. Villages taken into account in the analysis differ in the progress of development processes, morphological diversification of settlements developed around former villages and in the transformations of the habitat of the village (from fully preserved forms to the forms with partly or entirely changed farm buildings). In the case of peasant villages, the morphological transformations have a different scale, from the phase of the minimal transformations (e.g. Jerzmanowo), to the phase where the initial form of the village is becoming blurred and the inter-urban "conglomerate" is developing (Ołtaszyn - Wojszyce).
\end{abstract}

Keywords: morphological transformations, spatial development of the city, urban morphology, peasant villages, Wrocław.

Barbara Miszewska, dr hab. prof. UWr.

Uniwersytet Wrocławski, Instytut Geografii i Rozwoju Regionalnego, Zakład Geografii Społeczno-Ekonomicznej, pl. Uniwersytecki 1, 50-137 Wrocław

e-mail: barbara.lubicz-miszewska@uni.wroc.pl

Robert Szmytkie, dr hab.

Uniwersytet Wrocławski, Instytut Geografii i Rozwoju Regionalnego, Zakład Geografii Społeczno-Ekonomicznej, pl. Uniwersytecki 1, 50-137 Wrocław

e-mail: robert.szmytkie@uni.wroc.pl 